\title{
Pengembangan Alat Musschenbroek dan Panduan Praktikumnya untuk Membangun Inkuiri Siswa
}

\author{
Fathin Irina Diatri ${ }^{1)}$ Agus Suyatna $^{2)}$ Abdurrahman ${ }^{2)}$ \\ ${ }^{1)}$ Magister Keguruan IPA FKIP Universitas Lampung ${ }^{1)}$ \\ ${ }^{2)}$ Magister Keguruan IPA FKIP Universitas Lampung ${ }^{2)}$ \\ fathinirinadiatri@gmail.com
}

\begin{abstract}
This developmental research aims to produce Musschenbroek's apparatus with practice's guidance that not only can be utilized to determine compare coefficient effervesces length an object but can also be utilized to account coefficient point effervesces length and build inquiry's student. Development that doing based on ADDIE'S model. Procedure of this research and development is consisting of five phases, which is analysis, design, development, implementation, and evaluation. Result of this development is acquired Musschenbroek's apparatus that can applicable to account coefficient point effervesces length and practice's guidance that can build inquiry's student. Musschenbroek's apparatus that designing is interesting, easy, and very helpful for student bases on the result of field test. Developed practice's guidance have also interesting, easy, and helpful. Practice's guidance load learning steps that corresponding to build inquiry's student with pretty good category, which is on aspect makes hypothesis, collecting data, testing hypothesis, and formulates conclusion. Learning used Musschenbroek's apparatus and practice's guidance effective to increase student learning result with category moderate ( $n$-gain $=0,57)$.
\end{abstract}

Keywords : Musschenbroek's apparatus, Practice's guidance, Effervesce length, Inquiry.

(c) (7) This is an open access article distributed under the Creative Commons 4.0 Attribution License, which permits unrestricted use, distribution, and reproduction in any medium, provided the original work is properly cited. @2018 by author and Universitas Negeri Padang.

\section{PENDAHULUAN}

Ketercapaian hasil pembelajaran IPA secara umum masih tergolong rendah. Hal ini dapat terlihat dari analisis data TIMSS (Trends International in Mathematics and Science Study) dan PISA (Programme for International Student Assessment). Hasil TIMSS tahun 2011 menunjukkan Indonesia menduduki posisi ke-40 dari 42 negara pada bidang sains kelas 8 dengan rata-rata skor sebesar 406 (Martin, et al., 2012). Hasil PISA tahun 2018 menunjukkan bahwa literasi sains anak Indonesia (usia 15 tahun) menduduki peringkat ke-70 dari 78 negara dengan skor rata-rata 396 (OECD, 2019). Ratarata skor yang diperoleh Indonesia pada TIMSS dan PISA ini masih di bawah standar yang sebesar 500.

Hasil belajar dipengaruhi oleh banyak komponen dari proses pembelajaran, antara lain: tujuan, bahan atau materi, strategi pembelajaran, guru dan siswa sebagai subjek belajar, serta media pembelajaran (Sugandi, 2008). Media pembelajaran merupakan hal yang penting dalam kegiatan pembelajaran. Siswa dapat terbantu untuk memahami suatu materi pembelajaran jika materi tersebut dikemas dalam media pembelajaran yang sesuai (Siregar, 2015). Ketepatan pemilihan media juga dapat membantu memberi kejelasan pada objek yang diamati. Penggunaan media pembelajaran dapat mempertinggi proses dan hasil belajar, sehingga proses pembelajaran dapat berlangsung secara efektif dan efisien (Yulianti, 2010).

Media pembelajaran berupa alat praktikum merupakan media pembelajaran konkret yang dapat digunakan dalam pembelajaran. Penggunaan alat praktikum yang bersifat konkret ini dapat membantu siswa untuk membangun ide dan memahami materi pembelajaran dengan lebih utuh (Scardamalia dan Bereiter, 2006). Hal ini dikarenakan penggunaan alat praktikum dalam pembelajaran melibatkan semua indera (penglihatan, pendengaran, perasaan, penciuman, dan peraba) yang dikenal dengan learning by doing (Arsyad, 2015).

Alat praktikum yang dapat digunakan pada materi suhu dan perubahannya, khususnya pada konsep muai panjang adalah alat 
Musschenbroek. Observasi (pengamatan) dilakukan dengan menganalisis kekurangan alat Musschenbroek yang ada di lapangan. Berdasarkan hasil observasi, alat Musschenbroek yang ada di lapangan hanya dapat digunakan untuk mengetahui perbandingan koefisien muai panjang suatu benda padat (berbentuk batang), tetapi tidak dapat digunakan untuk menghitung nilai koefisien muai panjang masing-masing benda tersebut.

Kekurangan yang ada pada alat Musschenbroek tersebut menjadikan perlu adanya pengembangan alat Musschenbroek lebih lanjut. Sehingga alat Musschenbroek tidak hanya dapat digunakan untuk menghitung perbandingan koefisien muai panjang masingmasing batang, tetapi juga dapat digunakan untuk menghitung nilai koefisien muai panjangnya. Perlu adanya penambahan komponen berupa tempat meletakkan termometer agar suhu masing-masing batang dapat diketahui. Pemanas yang digunakan juga perlu diubah sehingga menghasilkan panas yang lebih stabil dan merata.

Selain pemilihan dan penggunaan media pembelajaran yang tepat, dibutuhkan pula model pembelajaran yang sesuai, sehingga tujuan pembelajaran dapat tercapai dengan baik. Terdapat berbagai model pembelajaran yang dapat digunakan dalam kegiatan pembelajaran, salah satunya yaitu model inkuiri. Model inkuiri merupakan model pembelajaran yang penting di antara berbagai model pembelajaran yang ada (Abdi, 2014). Penggunaan media pembelajaran konkret berbasis inkuiri dapat membantu siswa untuk meningkatkan pemahamannya terhadap materi yang abstrak, sehingga materi tersebut menjadi lebih bermakna (Özdýlek dan Bulunuz, 2009). Pembelajaran berbasis inkuiri menjadikan siswa terlibat aktif dalam membangun pengetahuannya melalui eksplorasi dan penelitian menggunakan berbagai sumber sehingga pemahaman mereka dapat meningkat (Kuhlthau, et al., 2008).

Pembelajaran berbasis inkuiri juga dapat membantu siswa untuk memperoleh pengetahuan secara utuh (Tangkas, 2012). Melalui pembelajaran berbasis inkuiri, siswa mengikutsertakan aktivitas dan proses berpikir yang ilmiah untuk menghasilkan pengetahuan baru, sehingga dapat memahami konsep, fakta, atau keterampilan dengan lebih spesifik. (Abdi, 2014). Pengetahuan yang diperoleh siswa juga tersimpan dalam memori jangka panjangnya karena siswa menemukan konsepnya sendiri (Tangkas, 2012).

Alat Musschenbroek yang didesain juga perlu dilengkapi dengan panduan praktikumnya. Pada kegiatan pembelajaran, panduan praktikum disajikan dalam bentuk LKS. LKS yang berisi panduan praktikum dapat membantu siswa memperoleh pengalaman secara langsung karena merupakan petunjuk atau pedoman dengan langkah-langkah penyelesaian tugas tertentu (Masithussyifa, dkk., 2012). Pemerolehan pengalaman langsung dapat menjadikan pemahaman siswa lebih bermakna dengan didukung oleh model inkuiri yang digunakan pada panduan praktikumnya. Panduan praktikum menggunakan model inkuiri juga memfasilitasi siswa untuk menemukan masalah sampai jawaban dari permasalahan tersebut (Munatri, 2016) sehingga dapat membantu menumbuhkan kemampuan ilmiah siswa.

Berdasarkan latar belakang masalah tersebut maka penelitian pengembangan ini bertujuan untuk: 1) menghasilkan alat Musschenbroek yang memiliki validitas tinggi pada materi suhu dan kalor yang dapat digunakan untuk mengukur koefisien muai panjang, 2) mendeskripsikan respon siswa terhadap alat Musschenbroek yang didesain, 3) mendeskripsikan efektivitas alat Musschenbroek yang didesain dalam membangun inkuiri siswa, 4) menghasilkan panduan praktikum yang valid, sesuai dengan alat Musschenbroek yang didesain.

\section{METODE PENELITIAN}

Penelitian ini menggunakan pendekatan mix method yaitu berupa metode penelitian dan pengembangan (research and development). Model pengembangan yang digunakan yaitu model ADDIE (Analysis - Design Development - Implementation - Evaluation).

Uji coba produk terdiri dari uji ahli, uji coba perseorangan, dan uji coba kelompok kecil. Setelah produk dinyatakan valid oleh para ahli (dosen dan guru IPA), selanjutnya produk diuji coba perseorangan. Uji coba perseorangan berupa uji satu lawan satu (one to one evaluation) untuk mengetahui penggunaan (keterpakaian) alat Musschenbroek yang dikembangkan serta mengecek keterbacaan dan kesalahan penulisan pada panduan 
praktikum.Setelah produk sesuai dengan hasil evaluasi yang dilakukan siswa pada uji coba perseorangan, maka selanjutnya dilakukan uji coba kelompok kecil.

Uji coba kelompok kecil menggunakan desain penelitian quasi experimental dengan rancangan the one-group posttest-only design yaitu memberikan perlakuan tertentu pada subjek, kemudian dilakukan pengukuran terhadap variabel tanpa adanya kelompok pembanding dan tes awal. Hasil yang diperoleh dari uji lapangan kelompok kecil menjadi indikasi kesiapan produk untuk digunakan dalam kegiatan pembelajaran pada uji lapangan. Sebelumnya, soal yang akan digunakan diuji validitas dan reliabilitas instrumen tesnya. Uji validitas dan reliabilitas ini diberikan kepada siswa yang sudah pernah memperoleh pembelajaran mengenai konsep muai panjang.

Uji lapangan diberikan kepada siswa kelas VII SMP sebagai subjek penelitian. Uji lapangan yang digunakan merupakan quasi eksperimen dengan rancangan the one-group pretest-posttest design. Siswa mengerjakan pretest sebelum diberi perlakuan, dan setelah perlakuan siswa diberi posttest. Uji lapangan ini dilakukan untuk mengetahui pengaruh penggunaan produk hasil pengembangan dalam mencapai tujuan pembelajaran.

Siswa dan guru pengamat juga diminta untuk mengisi angket mengenai pelaksanaan pembelajaran menggunakan produk hasil pengembangan. Angket ini bertujuan untuk mengetahui respon dari siswa dan guru mengenai proses pembelajaran yang telah dilakukan.

Kemampuan inkuiri siswa diukur dari hasil pekerjaan siswa yang dilakukan selama pembelajaran menggunakan alat Musschenbroek hasil pengembangan dan panduan praktikumnya. Kemampuan inkuiri siswa juga dilihat berdasarkan penilaian diri sendiri yang dilakukan oleh siswa pada penilaian kinerja dan respon siswa mengenai proses pembelajaran.

Pengembangan yang dilakukan dinyatakan efektif jika terjadi peningkatan pada kemampuan siswa setelah pembelajaran menggunakan alat Musschenbroek yang didesain. Efektivitas ini dapat diperoleh dari hasil pengukuran hasil pembelajaran melalui pretest dan posttest pada uji lapangan.

\section{HASIL DAN PEMBAHASAN}

\section{Analysis (Analisis)}

Analisis dilakukan melalui dua tahap kegiatan, yaitu analisis kebutuhan dan studi literatur. Pada tahap analisis kebutuhan, alat Musschenbroek yang sudah ada di lapangan dianalisis kekurangannya. Berdasarkan hasil analisis, alat Musschenbroek yang sudah ada hanya dapat digunakan untuk mengetahui jenis benda padat (berbentuk batang) yang memiliki koefisien muai lebih besar maupun lebih kecil, tetapi tidak dapat mengetahui besar nilai koefisien muai panjang pada masing-masing batang tersebut, sehingga diperlukan pengembangan alat Musschenbroek lebih lanjut.

\section{Design (desain)}

Pengembangan yang dilakukan dirancang pada tahap ini. Rancangan pengembangan yang dibuat yaitu desain alat Musschenbroek yang diinginkan, format panduan praktikum yang akan dibuat, perencanaan instrumen yang akan digunakan, dan perencanaan perangkat pembelajaran yang diperlukan.

Pengembangan alat Musschenbroek dilakukan dengan menambahkan tempat dudukan untuk meletakkan termometer. Penambahan tempat termometer ini menjadikan perubahan suhu yang dialami batang dapat diketahui dengan lebih mudah, sehingga koefisien muai masing-masing batang juga dapat dihitung. Penggunaan pembakar spirtus sebagai pemberi kalor pada batang juga perlu diperbaiki. Hal ini dikarenakan kalor yang diterima batang dari pembakar spirtus kemungkinan tidak merata, sehingga hasil perbandingan pemuaian panjang masing-masing batang menjadi tidak akurat. Pengembangan yang dapat dilakukan untuk mengurangi kemungkinan ketidakakuratan hasil yang diperoleh adalah dengan mengganti penghasil kalor dari pembakar spirtus tersebut dengan elemen pemanas listrik. Kalor yang dihasilkan oleh elemen pemanas listrik lebih stabil dan dapat menjadikan hasil pengukuran yang diperloleh juga menjadi lebih akurat.

Alat Musschenbroek yang dikembangkan dilengkapi panduan praktikum sebagai petunjuk penggunaan agar dapat dimanfaatkan dengan lebih maksimal. Panduan praktikum dikembangkan dengan menerapkan model pembelajaran inkuiri terbimbing. Panduan 
praktikum ini berisi serangkaian komponen kegiatan dan penugasan yang dapat digunakan siswa untuk berkerja secara ilmiah. Komponen tersebut yaitu: 1) petunjuk belajar yang berisi panduan awal penggunaan panduan praktikum, 2) informasi tentang kompetensi inti (KI) dan kompetensi dasar (KD) yang harus dicapai siswa, 3) informasi tentang bagian-bagian alat Musschenbroek, 4) orientasi (informasi awal) untuk mengarahkan pemikiran siswa, 5) tujuan percobaan yang akan dilakukan, 6) alat dan bahan yang dibutuhkan dalam percobaan, 7) rumusan masalah yang akan dicari tahu jawabannya, 8) hipotesis atau dugaan awal yang akan diuji kebenarannya, 9) variabel-variabel yang ada dalam percobaan, 10) langkah praktikum yang akan membimbing siswa ketika melakukan percobaan, 11) tabel hasil pengamatan untuk memfokuskan siswa pada apa yang diteliti, 12) grafik untuk menggambarkan hasil pengamatan dengan lebih jelas, 13) pertanyaan-pertanyaan analisis tentang hasil percobaan yang telah dilakukan sebagai pembangun konsep siswa untuk menarik kesimpulan, 14) kesimpulan yang diperoleh siswa berdasarkan pembelajaran yang telah dilaksanakan.

\section{Development (pengembangan)}

Rancangan yang telah dibuat pada tahap desain selanjutnya dilakukan pengembangan lebih lanjut. Prototipe 1 menggunakan alat Musschenbroek yang yang sudah ada di lapangan.Alat Musschenbroek yang sudah ada ini ditambahkan komponen pemanas. Pada rangkaian listrik pemanas ini juga ditambahkan thermofuse yang secara otomatis dapat memutuskan arus jika suhu yang dihasilkan sudah terlalu tinggi.

Pada prototipe 1 juga ditambahkan tempat untuk meletakkan termometer pada masingmasing batang. Tempat termometer ini terbuat dari bahan pertinax (fiber), atau yang dikenal juga dengan nama ebonit. Alasan pemilihan bahan ini dikarenakan pertinax aman digunakan pada suhu yang tinggi dan bukan merupakan penghantar panas yang baik, sehingga suhu yang ditunjukkan oleh masing-masing termometer yang diletakkan pada tempat termometer ini benar-benar merupakan suhu dari tiap batang yang diukur.

Sebuah dudukan juga ditambahkan pada prototipe 1 alat Musschenbroek. Dudukan ini berfungsi sebagai tempat terpasangnya elemen pemanas. Elemen pemanas yang digunakan pada prototipe 1 alat Musschenbroek adalah elemen pemanas kertas dengan daya 300 watt. Besarnya daya pada elemen pemanas kertas menjadikan panas yang dihasilkan juga besar. Prototipe 1 yang telah ditambahkan dengan tempat dudukan termometer dan dudukan pemanas dapat dilihat pada Gambar 1. Prototipe 1 ditambahkan pula potongan logam untuk menahan batang agar tidak terangkat akibat pemuaian yang terjadi pada pemanas yang digunakan.

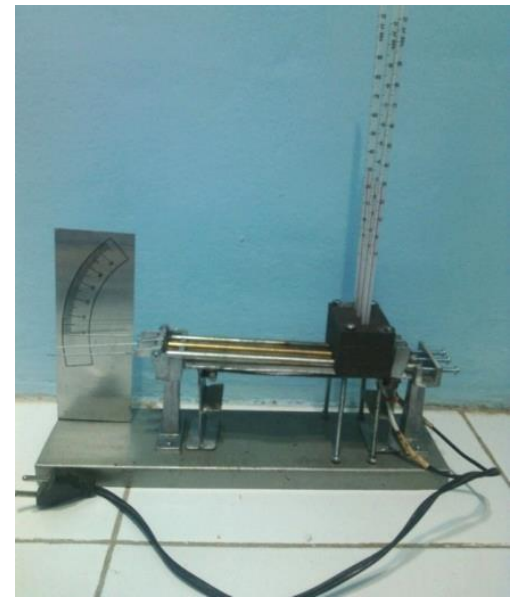

Gambar 1 Prototipe 1 Alat Musschenbroek

Kemudian dilakukan uji coba mandiri untuk melihat apakah prototipe 1 alat Musschenbroek berfungsi sesuai dengan baik. Hasil uji coba menunjukkan bahwa pemanas sudah efektif untuk digunakan. Hal ini dikarenakan pemanas dapat dapat menaikkan suhu batang dengan cepat menjadikan waktu yang dibutuhkan untuk melakukan percobaan menjadi lebih sedikit, sehingga waktu yang digunakan dalam pembelajaran menjadi lebih efisien. Adapun hasil uji cobanya dapat dilihat pada Tabel 1.

Tabel 1 Hasil Uji Coba Prototipe 1 Alat Musschenbroek

\begin{tabular}{ccccc}
\hline \multirow{2}{*}{ Jenis Batang } & $\begin{array}{c}\text { Panjang } \\
\text { Awal }\end{array}$ & $\begin{array}{c}\text { Suhu } \\
\text { Awal }\end{array}$ & $\begin{array}{c}\text { Suhu } \\
\text { Akhir }\end{array}$ & Skala \\
\hline Besi & $19,4 \mathrm{~cm}$ & $29^{\circ} \mathrm{C}$ & $103^{\circ} \mathrm{C}$ & 11,0 \\
Kuningan & $19,4 \mathrm{~cm}$ & $29^{\circ} \mathrm{C}$ & $98^{\circ} \mathrm{C}$ & 6,5 \\
Alumunium & $19,4 \mathrm{~cm}$ & $29^{\circ} \mathrm{C}$ & $94^{\circ} \mathrm{C}$ & 4,0 \\
\hline
\end{tabular}

Hasil uji coba pada Tabel 1 digunakan sebagai data untuk menghitung nilai konversi skala yang ditunjukkan oleh jarum penunjuk pada alat Musschenbroek yang didesain. 
Setelah dilakukan perhitungan, diperoleh nilai konversinya sebesar 0,0037 . Nilai konversi ini berarti setiap 1 skala yang ditunjukkan oleh jarum penunjuk menyatakan terjadi perubahan (pertambahan) panjang batang sebesar 0,0037 $\mathrm{cm}$, atau $0,037 \mathrm{~mm}$.

Adanya nilai konversi ini menjadikan besarnya pertambahan panjang batang dapat diketahui. Nilai panjang awal, besar pertambahan panjang setelah dipanaskan, dan perubahan suhu yang dialami batang menjadikan nilai koefisien muai panjang masing-masing batang juga dapat dihitung menggunakan rumus.

Selanjutnya disiapkan pula panduan praktikum sebagai panduan untuk penggunaan prototipe 1 alat Musschenbroek yang didesain. Panduan praktikum yang dikembangkan menggunakan sintaks inkuiri terbimbing sesuai dengan desain yang direncanakan.

Prototipe 1 alat Musschenbroek yang didesain dan panduan praktikumnya kemudian diuji oleh para ahli.Para ahli penguji kevalidan produk terdiri dari 3 orang dosen sebagai pakar dan 2 orang guru IPA sebagai praktisi. Berdasarkan hasil validitas alat Musschenbroek yang didesain, diperoleh rata-rata skor total validitas alat Musschenbroek yang didesain sebesar 8,90 dengan kategori sangat baik. Sedangkan panduan praktikumnya memeroleh rata-rata skor total validitas panduan praktikum sebesar 9,53 dengan kategori sangat baik. Hasil uji ahli tersebut menunjukkan bahwa alat Musschenbroek dan panduan praktikumnya dapat diuji cobakan ke sekolah. Sebelum diujicobakan ke siswa, terdapat beberapa saran sebagai perbaikan produk yang diberikan oleh para ahli. Saran perbaikan ini digunakan sebagai penyempurna produk yang dihasilkan.

Prototipe 1 alat Musschenbroek beserta panduan praktikum yang telah disempurnakan berdasarkan saran para ahli selanjutnya disebut prototipe 2. Prototipe 2 alat Musschenbroek yang didesain dilengkapi dengan stop kontak yang memiliki lampu indikator. Ketika stop kontak dalam posisi on, lampu indikatornya akan menyala, sehingga dapat memermudah mengetahui apakah pemanas sudah terhubung dengan arus listrik atau belum.

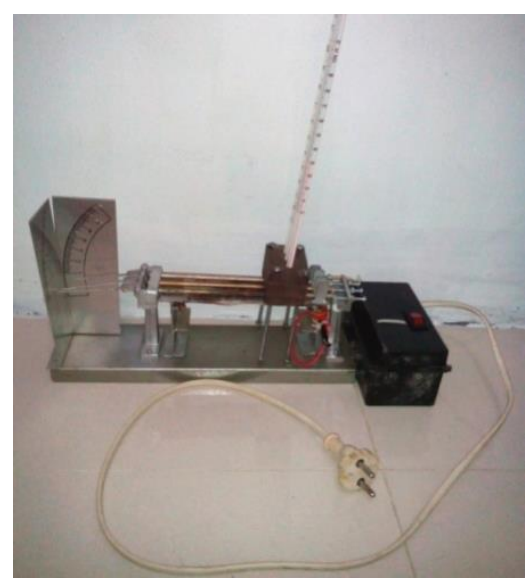

Gambar 2 Prototipe 2 Alat Musschenbroek

Prototipe 2 alat Musschenbroek yang didesain juga dilengkapi dengan kotak penyimpanannya. Kotak penyimpanan prototipe 2 alat Musschenbroek ini dibuat menggunakan karton dengan ketebalan 2,5 mm. Di dalamnya juga terdapat kotak tambahan untuk penyimpanan termometer dan batang yang akan digunakan. Kotak tambahan ini dibuat menggunakan karton dengan ketebalan yang lebih tipis, yaitu hanya $1,5 \mathrm{~mm}$.

Sebelum prototipe 2 diujicobakan ke siswa kelas VII sebagai subjek penelitian, soal tes yang akan digunakan diujikan diuji validitas dan reliabilitasnya. Soal tes diberikan pada 30 orang siswa kelas VIII A di SMPN 14 Bandar Lampung. Berdasarkan hasil analisis validitas dan reliabilitas yang telah dilakukan, diperoleh hasil bahwa 10 butir soal tes yang akan digunakan sudah valid dan reliabel. Sehingga soal tes tersebut dapat digunakan untuk uji coba selanjutnya.

Prototipe 2 alat Musschenbroek dan panduan praktikumnya selanjutnya diujicobakan ke siswa. Uji coba yang pertama dilakukan berupa uji coba perseorangan. Uji coba perseorangan diberikan kepada 3 orang siswa kelas VII di SMPN 14 Bandar Lampung. Berdasarkan hasil angket yang diberikan, diperoleh rata-rata skor hasil uji alat Musschenbroek yang didesain sebesar 3,3 (sangat baik) dan rata-rata skor hasil uji panduan praktikum sebesar 3,4 (sangat baik). Berdasarkan hasil uji coba perseorangan, prototipe 2 alat Musschenbroek dapat digunakan dan panduan praktikum sudah tidak ada kesalahan keterbacaan. Sehingga produk dapat diuji coba selanjutnya dan disebut sebagai prototipe 3.

Selanjutnya dilakukan uji coba kelompok kecil. Prototipe 3 alat Musschenbroek dan 
panduan praktikumnya diujikan pada 15 orang siswa kelas VII SMPN 14 Bandar Lampung. Siswa tersebut diberikan pembelajaran pemuaian panjang menggunakan prototipe 3 . Pada akhir pembelajaran, siswa diberikan soal posttest. Diperoleh rata-rata hasil posttest siswa pada uji coba kelompok kecil sebesar 69,67. Siswa juga diberikan angket mengenai prototipe 3. Berdasarkan hasil angket, diperoleh rata-rata skor hasil uji alat Musschenbroek yang dikembangkan sebesar 3,2 (baik) dan rata-rata skor hasil uji panduan praktikum sebesar 3,0 (baik).

Selanjutnya produk disebut sebagai prototipe 4. Hasil uji coba kelompok kecil ini menunjukkan bahwa prototipe 4 alat Musschenbeoek dan panduan praktikumnya sudah dapat digunakan dalam pembelajaran.

\section{Implementation (implementasi)}

Implementasi dilakukan dengan menerapkan prototipe 4 di kelas melalui uji lapangan. Kelas yang digunakan pada uji lapangan adalah kelas VII F di SMPN 14 Bandar Lampung dengan jumlah siswa sebanyak 30 siswa. Sebelum kegiatan pembelajaran dilaksanakan, siswa diberikan soal pretest. Kemudian siswa melaksanakan pembelajaran menggunakan prototipe 4 alat Musschenbroek dan panduan praktikumnya.

Setelah pembelajaran, siswa diberikan angket yang terdiri dari 9 item mengenai alat Musschenbroek hasil pengembangan dan 15 soal mengenai LKS panduan praktikum. Berdasarkan hasil angket pada uji lapangan diperoleh nilai kemenarikan, kemudahan, dan kemanfaatan produk seperti yang disajikan pada Tabel 2.

Tabel 2 Hasil Angket Uji Lapangan

\begin{tabular}{|c|c|c|c|}
\hline No. & Aspek & $\begin{array}{c}\text { Skor } \\
\text { Rata- } \\
\text { rata }\end{array}$ & $\begin{array}{c}\text { Pernyataan } \\
\text { Kualitatif }\end{array}$ \\
\hline \multicolumn{4}{|c|}{ Alat Musschenbroek } \\
\hline 1 & Kemenarikan & 3,24 & Menarik \\
\hline 2 & Kemudahan & 3,02 & Mudah \\
\hline 3 & Kemanfaatan & 3,41 & $\begin{array}{c}\text { Sangat } \\
\text { bermanfaat }\end{array}$ \\
\hline \multicolumn{4}{|c|}{ Panduan Praktikum } \\
\hline 1 & Kemen & 3,13 & $\mathrm{Me}$ \\
\hline 2 & Kemu & 3,07 & Mudah \\
\hline 3 & Kemanfaatan & 3,17 & Bermanfaat \\
\hline
\end{tabular}

Selanjutnya siswa diberi soal posttest. Nilai rata-rata pretest siswa yang diperoleh sebesar 43,83 dan rata-rata posttest sebesar 75,83. Hasil pretest dan posttest yang telah diperoleh selanjutnya dicari nilai n-gainnya. Nilai n-gain yang diperoleh yaitu sebesar 0,57. Nilai n-gain tersebut menunjukkan bahwa penggunaan produk hasil pengembangan memberikan peningkatan hasil pembelajaran dengan kategori sedang.

Ada atau tidaknya pengaruh pembelajaran menggunakan alat Musschenbroek yang didesain beserta panduan praktikumnya dalam meningkatkan hasil belajar siswa juga diperoleh dari hasil uji statistik. Uji yang dilakukan berupa uji paired sample t-test karena data berdistribusi normal berdasarkan hasil uji normalitas pretest-posttest shapiro wilk. Berdasarkan uji paired sample t-test dapat disimpulkan bahwa ada perbedaan rata-rata antara hasil belajar pretest dengan posttest yang artinya ada pengaruh pembelajaran menggunakan alat Musschenbroek yang didesain beserta panduan praktikumnya dalam meningkatkan hasil belajar siswa kelas VII SMPN 14 Bandar Lampung Tahun Ajaran 2019/2020.

Nilai n-gain dan hasil uji statistik menunjukkan pembelajaran sudah efektif. Hasil yang diperoleh sejalan dengan hasil penelitian Kartikarini dan Prabowo (2016) bahwa adanya peningkatan nilai tes dalam kategori sedang setelah alat peraga pemuaian panjang diterapkan di kegiatan pembelajaran.

Kemampuan guru dalam mengelola pembelajaran juga diamati menggunakan angket. Berdasarkan hasil angket tersebut, diketahui bahwa guru mengelola pembelajaran dengan kategori sangat baik dengan skor total sebesar 9,50. Siswa juga diberikan angket mengenai pembelajaran yang telah dilaksanakan. Hasil angket respon siswa menunjukkan pembelajaran sudah terlaksana dengan sangat baik, rata-rata skor total 8,4.

\section{Evaluation (evaluasi)}

Evaluasi sudah dilakukan pada setiap tahap uji. Hasil evaluasi digunakan untuk memberi umpan balik berupa revisi atau perbaikan. Perbaikan ini dilakukan untuk memeroleh produk yang sesuai, layak, dan efektif untuk digunakan sebagai pembelajaran di sekolah. 
Pembelajaran dilakukan menggunakan model pembelajaran inkuiri terbimbing. Langkah-langkah inkuiri menurut Hosnan (2014) yaitu orientasi, merumuskan masalah, merumuskan hipotesis, mengumpulkan data, menguji hipotesis, dan merumuskan kesimpulan. Sintaks inkuiri tersebut menjadi format dasar pada panduan praktikum. Sehingga panduan praktikum juga dapat digunakan untuk mengukur kemampuan inkuiri siswa.

Kemampuan inkuiri merupakan kemampuan siswa dalam melakukan kegiatan pembelajaran menggunakan sintaks inkuiri. Kemampuan inkuiri siswa yang diamati pada penelitian pengembangan ini dibatasi hanya pada aspek membuat hipotesis, mengumpulkan data, menguji hipotesis, dan merumuskan kesimpulan.

Kemampuan inkuiri siswa diukur berdasarkan hasil pekerjaan siswa pada panduan praktikum yang digunakan selama pembelajaran menggunakan alat Musschenbroek yang didesain, penilaian diri sendiri oleh siswa pada penilaian kinerja dan angket respon siswa mengenai proses pembelajaran. Ketiga hasil kemampuan inkuiri siswa tersebut kemudian dicari nilai rata-ratanya (Tabel 3).

Tabel 3 Rata-rata Kemampuan Inkuiri Siswa

\begin{tabular}{lrc}
\hline No Aspek Inkuiri & Rata-rata & Kategori \\
\hline 1. Membuat hipotesis & 8,03 & Sangat baik \\
\hline 2. Mengumpulkan data & 8,94 & Sangat baik \\
\hline 3. Menguji hipotesis & 7,76 & Sangat baik \\
\hline $\begin{array}{l}\text { 4. Merumuskan } \\
\text { kesimpulan }\end{array}$ & 8,37 & Sangat baik \\
\hline Rata-rata & $\mathbf{8 , 2 8}$ & Sangat baik \\
\hline
\end{tabular}

Hipotesis dibuat berdasarkan rumusan masalah yang sudah dibuat sebelumnya. Siswa masih membutuhkan bimbingan guru untuk membuat hipotesis, karena siswa masih belum terbiasa membuat hipotesis. Hal ini sejalan dengan penelitian Rohmah, dkk (2017) bahwa siswa kelas VII yang menjadi subjek penelitiannya mengalami kesulitan untuk membuat hipotesis.

Mengumpulkan data merupakan aktivitas mengumpulkan informasi yang dibutuhkan untuk menguji hipotesis yang telah dibuat.
Siswa mencatat hasil percobaan dan menjawab pertanyaan analisis mengenai percobaan yang telah dilakukan untuk membuktikan apakah hipotesis mereka benar atau tidak. Pertanyaan dapat menuntun siswa untuk melakukan penyelidikan sebagai usaha dalam memahami materi pelajaran (Zubaidah, dkk.: 2013). Meskipun kemampuan siswa pada aspek mengumpulkan data memperoleh nilai rata-rata yang terbesar, siswa masih membutuhkan bimbingan pada saat melaksanakan percobaan maupun saat menjawab pertanyaan analisis.

Menguji hipotesis merupakan proses menetukan jawaban yang dianggap diterima sesuai dengan data atau informasi yang diperoleh berdasarkan pengumpulan data. Kemampuan siswa pada aspek menguji hipotesis memeroleh hasil rata-rata yang terkecil, hal ini dikarenakan siswa masih belum terbiasa dengan hipotesis. Sehingga siswa masih belum merasa yakin dengan hipotesis yang sudah dibuatnya.

Merumuskan kesimpulan merupakan proses mendeskripsikan temuan yang diperoleh berdasarkan hasil pengujian hipotesis dengan generalisasi. Siswa sudah mampu merumuskan kesimpulan walaupun masih membutuhkan bimbingan guru.

Berdasarkan Tabel 3 diperoleh rata-rata kemampuan inkuiri siswa sebesar 8,28 dengan kategori sangat baik. Hasil ini menunjukkan bahwa siswa sudah memiliki kemampuan untuk melaksanakan pembelajaran inkuiri terbimbing. Hasil yang diperoleh ini sejalan dengan hasil penelitian Bulan dkk. (2015) bahwa pembelajaran inkuiri terbimbing menjadikan 85\% siswa memiliki kemampuan inkuiri berkategori baik.

Meskipun rata-rata kemampuan inkuiri siswa sudah sangat baik, siswa masih membutuhkan bimbingan guru pada saat pelaksanaan pembelajarannya. Hal ini dikarenakan siswa kelas VII masih belum terbiasa melakukan pembelajaran berbasis inkuiri. Siswa membutuhkan adaptasi karena masih merasa asing dengan pembelajaran inkuiri (Bulan dkk., 2015).

Alat Musschenbroek yang didesain memiliki kelebihan sebagai berikut: 1) alat Musschenbroek yang didesain tidak hanya dapat digunakan untuk menunjukkan adanya pemuaian panjang dan perbedaan kemampuan memuai untuk benda yang berbeda, tetapi juga dapat digunakan untuk menghitung nilai koefisien muai panjangnya, 2) sekolah yang 
sebelumnya sudah memiliki alat Musschenbroek yang ada di lapangan tidak perlu membeli alat yang baru, tetapi cukup menambahkan elemen pemanas listrik dan komponen untuk mengukur suhunya, 3) jika terjadi kendala listrik yang tidak dapat digunakan saat pembelajaran akan dilaksanakan, guru tetap dapat menggunakan spirtus sebagai pemanas batang pada alat Musschenbroek yang didesain. Sehingga pembelajaran dapat tetap terlaksana sesuai rencana.

Meskipun memiliki kelebihan, alat Musschenbroek yang didesain juga masih memiliki kelemahan sebagai berikut: 1) dibutuhkan ketelitian yang tinggi dalam pengoperasian alat Musschenbroek yang didesain. Ketelitian ini diperlukan ketika pengaturan baut pada pangkal batang sehingga jarum penunjuk tepat berimpit dengan angka nol pada skalanya. Ketelitian juga dibutuhkan pada saat pembacaan besarnya suhu pada thermometer dan pembacaan nilai skala yang ditunjukkan oleh jarum penunjuk. Jika kurang teliti, maka hasil percobaan yang diperoleh akan memiliki tingkat kesalahan yang besar, 2) perlu berhati-hati untuk tidak sembarangan menyentuh alat Musschenbroek yang didesain ketika melaksanakan praktikum, karena terjadi peningkatan suhu dari pemanas yang digunakan, 3) termometer sebagai komponen alat yang digunakan perlu diperhatikan apakah masih berfungsi dengan baik. Apabila perubahan suhu yang terjadi tidak dapat diukur dengan tepat maka hasil percobaan yang diperoleh akan menjadi tidak akurat, 4) jumlah alat Musschenbroek yang didesain masih terbatas, sehingga tidak semua siswa mencoba menggunakan alat secara langsung, 5) percobaan tidak dapat diulang dalam waktu yang singkat, karena dibutuhkan waktu untuk mengembalikan suhu alat Musschenbroek menjadi normal. Sehingga percobaan harus dipersiapkan dengan matang.

\section{KESIMPULAN}

Kesimpulan dari penelitian pengembangan ini sebagai berikut: 1) dihasilkan alat Musschenbroek yang dapat digunakan untuk mengukur nilai koefisien muai panjang dengan rata-rata skor total validitas sebesar 8,90 (kategori sangat baik). Panas yang dihasilkan oleh pemanas lebih stabil dan merata dan terdapat dudukan untuk meletakkan termometer pada masing-masing logam, 2) berdasarkana hasil uji lapangan, alat Musschenbroek yang didesain dinyatakan menarik, mudah dan sangat bermanfaat, 3) nilai n-gain dan hasil uji statistik pada uji lapangan menunjukkan pembelajaran sudah efektif. Nilai n-gain yang diperoleh sebesar 0,57 menunjukkan bahwa penggunaan produk hasil pengembangan memberikan peningkatan hasil pembelajaran dengan kategori sedang. Hasil uji statistik menunjukkan bahwa ada pengaruh pembelajaran menggunakan alat Musschenbroek yang didesain beserta panduan praktikumnya dalam meningkatkan hasil belajar siswa kelas VII SMPN 14 Bandar Lampung Tahun Ajaran 2019/2020. Produk hasil pengembangan dapat membangun kemampuan inkuiri siswa dengan kategori sangat baik, 4) dihasilkan panduan praktikum yang sesuai dengan alat Musschenbroek yang didesain dengan rata-rata skor total validitas sebesar 9,53 (kategori sangat baik). Berdasarkana hasil uji lapangan, panduan praktikum dinyatakan menarik, mudah, dan bermanfaat. Panduan praktikum mengarahkan siswa untuk menghitung nilai koefisien muai panjang logam (besi, tembaga, dan aluminium) melalui pengukuran perubahan panjang logam setelah dipanaskan dan pengukuran kenaikan suhu masing-masing logam.

\section{DAFTAR PUSTAKA}

Abdi, A. (2014). The Effect of Inquiry-Based Learning Method on Students' Academic Achievement in Science Course. Universal Journal of Educational Research. 2(1): 3741.

Bulan, S.N., Maharta, N., \& Ertikanto, C. (2015). Pengaruh Kemampuan Inkuiri terhadap Hasil Belajar Fisika Berbantuan Virtual Laboratory.Jurnal Pembelajaran Fisika. 3(3)

Hosnan, M. (2014). Pendekatan Saintifik dan Kontekstual dalam Pembelajaran Abad 21.Jakarta: Ghalia Indonesia.

Kartikarini, F. D., \& Prabowo. (2016). Pengembangan Alat Peraga Pemuaian Panjang Sebagai Media Pembelajaran Fisika Sub Pokok Bahasan Suhu dan Pemuaian. Jurnal Inovasi Pendidikan Fisika. 5(3).8286.

Kuhlthau, C. C., Maniotes, L. K., \& Caspari, A. K. (2008). Guided Inquiry: Learning in the 21st Century.Rutgers Center for 
International Scholarship in School Libraries.

Martin, M. O., Mullis, I. V., Foy, P., \& Stanco, G. M. (2012). TIMSS 2011 International Results in Science. International Association for the Evaluation of Educational Achievement. Herengracht 487: Amsterdam, 1017 BT, The Netherlands.

Masithussyifa, R. K. A., Ibrahim, M., \& Ducha, N. (2012). Pengembangan Lembar Kegiatan Siswa (LKS) Berorientasi Keterampilan Proses pada Pokok Bahasan Sistem Pernapasan Manusia. Jurnal Pendidikan Unesa IPA, 1(1), 7-10.

Munatri, S. (2016). Penerapan Model Pembelajaran Inkuiri Terbimbing untuk Meningkatkan Hasil Belajar Siswa pada Materi Sifat Koligatif Larutan di Kelas XI TKJ SMK Negeri 1 Buay Bahuga. (Doctoral Dissertation, Universitas Lampung).

OECD. (2019). PISA 2018 Results (Volume I): What Students Know and Can Do. Paris: PISA, OECD Publishing.

Özdýlek, Z. dan Bulunuz, N. (2009). The effect of a guided inquiry method on pre-service teacher's science teaching self-efficacy beliefs.Journal of Turkish Science Education. 6(2), 24.

Rohmah, K., Susilawati, dan Septaningrum, E. (2017). Penggunaan Alat Peraga Musschenbroek Bimetal terhadap Keterampilan Proses Sains. Jurnal Penelitian Pembelajaran Fisika. 8(2): 89-94

Scardamalia, M. dan Bereiter, C. (2006). Knowledge building: Theory, pedagogy, and technology. In K. Sawyer (Ed.), The Cambridge Handbook of the Learning Sciences (pp. 97-118). New York: Cambridge University Press.

Siregar, S. (2015). Pengaruh Model Pembelajaran Inkuiri Berbasis Media Animasi terhadap Pemahaman Konsep, Sikap Ilmiah dan Assesmen Kinerja Siswa Pada Konsep Sintesis Protein.Jurnal Edu Bio Tropika. 1(2).

Sugandi, A. (2008). Teori Pembelajaran. Semarang: Unnes Press.

Tangkas, I. M. (2012). Pengaruh implementasi model pembelajaran inkuiri terbimbing terhadap kemampuan pemahaman konsep dan keterampilan proses sains siswa kelas $\mathrm{X}$ SMAN 3 Amlapura. Jurnal Pendidikan IPA. 2(1).
Yulianti, D. (2010). Media Pembelajaran. Semarang: Fakultas MIPA Unnes.

Zubaidah, S., Yuliati, L., \& Mahanal, S. (2013). Model dan Metode Pembelajaran SMP IPA. Malang: Universitas Negeri Malang. 